\title{
Performance of dairy cows fed rations produced with sugarcane silages treated with additives or fresh sugarcane
}

\author{
André de Faria Pedroso ${ }^{1}$, Luiz Gustavo Nussio ${ }^{2}$, Armando de Andrade Rodrigues ${ }^{1}$, Flávio \\ Augusto Portela Santos ${ }^{2}$, Gerson Barreto Mourão ${ }^{2}$, Waldomiro Barioni Júnior ${ }^{1}$ \\ 1 Embrapa Pecuária Sudeste, São Carlos, SP - Brazil. \\ 2 USP/ESALQ - Depto. de Zootecnia, Piracicaba, SP - Brazil.
}

\begin{abstract}
An experiment was performed aiming at evaluating the performance of dairy cows fed sugarcane silages treated with additives compared to cows fed fresh forage. Twenty-four Holstein cows were grouped in blocks of three cows, according to parity order and milk production level, in multiple $3 \times 3$ Latin Square design to evaluate three types of ration (63\% roughage and $37 \%$ concentrate in dry matter - DM): ration with silage treated with urea $(5.0 \mathrm{~g} / \mathrm{kg}$ of fresh forage - FF) + sodium benzoate $(0.5 \mathrm{~g} / \mathrm{kg} \mathrm{FF})$; ration with silage inoculated with Lactobacillus buchneri $\left(5 \times 10^{4} \mathrm{cfu} / \mathrm{g} \mathrm{FF}\right)$; ration with fresh sugarcane. Each evaluation period consisted of two weeks for adaptation and one week for data collection. Cows fed rations with silages treated with urea + benzoate and L. buchneri showed lower DM intake (18.5 vs $21.4 \mathrm{~kg} /$ day) and lower milk production (17.4 vs $18.6 \mathrm{~kg} /$ day) in comparison to those fed fresh forage ration. Fat content was higher in the milk of cows fed silage inoculated with $L$. buchneri compared to cows in the fresh forage group resulting in similar $3.5 \%$ fat corrected milk (FCM) among cows in both groups. Cows fed ration with silage treated with urea + benzoate presented intermediate fat content in milk but inferior FCM production compared to animals fed fresh sugarcane. Feed efficiency (kg FCM/kg DMI) was higher for cows fed ration produced with the inoculated silage (0.95), intermediate for cows that received silage treated with the combination of chemical additives (0.91) and lower for cows fed the ration with fresh sugarcane $(0.83)$.
\end{abstract}

Key Words: feed efficiency, L. Buchneri, milk composition, milk production, sodium benzoate, urea

\section{Desempenho de vacas leiteiras alimentadas com rações produzidas com silagens de cana-de-açúcar tratadas com aditivos ou cana-de-açúcar fresca}

RESUMO - Um experimento foi realizado com o objetivo de avaliar o desempenho de vacas leiteiras alimentadas com silagens de cana-de-açúcar tratadas com aditivos em comparação ao de vacas alimentadas com a forragem fresca. Vinte e quatro vacas holandesas foram agrupadas em blocos de três vacas, de acordo com a ordem do parto e com o nível de produção de leite, em um delineamento quadrado latino múltiplo $3 \times 3$, para avaliação de três tipos de ração (63\% volumoso e 37\% concentrado na matéria seca - MS): ração com silagem tratada com ureia (5,0 g/kg de matéria verde - MV) + benzoato de sódio (0,5 g/kg MV); ração com silagem inoculada com Lactobacillus buchneri (5 × 10 4 ufc/g MV); ração com cana-de-açúcar fresca. Cada período de avaliação foi composto de duas semanas de adaptação e uma semana de coleta de dados. As vacas alimentadas com as rações com silagens tratadas com ureia + benzoato e com $L$. buchneri tiveram menor consumo de matéria seca (18,5 vs $21,4 \mathrm{~kg} /$ dia) e menor produção de leite (17,4 vs $18,6 \mathrm{~kg} /$ dia) em comparação àquelas alimentadas com a ração com forragem fresca. O teor de gordura no leite das vacas que receberam silagem inoculada com $L$. buchneri foi mais alto que no daquelas alimentadas com forragem fresca, o que resultou em valor de produção de leite corrigida para 3,5\% de gordura (LCG) similar entre os grupos. As vacas que receberam ração com silagem tratada com ureia + benzoato apresentaram nível intermediário de gordura no leite, mas produção inferior de leite corrigida em comparação às alimentadas com cana fresca. A eficiência alimentar (kg LCG/kg MS consumida) foi mais alta nas vacas alimentadas com a ração produzida com silagem inoculada $(0,95)$, intermediária para as vacas que receberam silagem tratada com a combinação de aditivos químicos $(0,91)$ e mais baixa para as vacas alimentadas com a cana-de-açúcar fresca $(0,83)$.

Palavras-chave: benzoato de sódio, composição do leite, L. buchneri, produção de leite, eficiência alimentar, ureia

\section{Introduction}

Sugarcane is broadly used as supplement forage in Brazil during the dry winter season. Traditionally, small plots are daily harvested and offered green chopped to the animals but the need for more efficiency in farm management has led to the increase in its use as silage. Ensilage can be advantageous since it avoids daily operations of 
harvesting, chopping and hauling of the crop. However, sugarcane silages are characterized by intense alcoholic fermentation, which results in high dry matter (DM) losses and great reductions in forage quality (Alli et al., 1982; Pedroso et al., 2005).

Several products have been evaluated in their capacity to control yeast development in these silages. Among the most studied additives are urea, sodium benzoate and inoculants containing the heterolactic bacteria Lactobacillus buchneri. These additives have reduced ethanol production and improved fermentation in the silages (Siqueira et al., 2007; Pedroso et al., 2008a). Effects of urea application in a low dose $(5.0 \mathrm{~g} / \mathrm{kg}$ fresh forage - FF) have been variable and high doses (10 to $15 \mathrm{~g} / \mathrm{kg} \mathrm{FF}$ ) may impair pH drop and enhance dry matter losses (Siqueira et al., 2007). Results from L. buchneri and benzoate application have also been variable. Better results were obtained when urea and benzoate were applied simultaneously in low doses (5.0 and $0.5 \mathrm{~g} / \mathrm{kg}$ FF, respectively). Pedroso et al. (2007) observed positive and synergistic effect when these additives were combined and in a subsequent trial the efficiency of the mixture in reducing ethanol production was confirmed (Pedroso et al., 2008b).

Information on the nutritive value for dairy cattle of sugarcane silages treated with chemical and bacterial additives is still scarce. Pedroso et al. (2006) observed improved daily gain and better feed conversion for Holstein heifers fed rations containing silages treated with $L$. buchneri or sodium benzoate relative to animals fed untreated silage while silage treated with urea ( $5 \mathrm{~g} / \mathrm{kg} \mathrm{FF}$ ) had no effect over animal performance. Queiroz et al. (2008) reported similar productions of milk and fat corrected milk for cows fed rations based on sugarcane silage treated with L. buchneri, corn silage or fresh sugarcane, but feed efficiency was lower for cows in the sugarcane silage treatment.

This research aimed at evaluating the performance of dairy cows fed rations based on sugarcane silages treated with urea + sodium benzoate or $L$. buchneri in comparison with performance of cows fed ration produced with fresh sugarcane.

\section{Material and Methods}

Twenty-four Holstein cows (five months in milk on average) were grouped in blocks of three cows, according to parity and milk production, in a multiple $3 \times 3$ Latin square design, to evaluate three types of total mixed rations - TMR: ration with sugarcane silage treated with urea $(5.0 \mathrm{~g} / \mathrm{kg}$ of fresh forage - FF) + sodium benzoate $(0.5 \mathrm{~g} / \mathrm{kg} \mathrm{FF})$; ration with sugarcane silage inoculated with L. buchneri $\left(5 \times 10^{4}\right.$ cfu/g FF); ration with fresh sugarcane. Cows from each block were randomly assigned to one of three confinement areas where the experimental ration was given to the group. The confinement areas had shades provided by trees and water troughs. Each evaluation period consisted of two weeks for adaptation and one week for data collection.

The sugarcane used to produce silages and to be given fresh to the animals was from the variety RB85-5536 (UFSCAR, Araras, São Paulo), at approximately 12 months of age, second cut. The forage was mechanically harvested with a harvester adjusted for a theoretical cut length between 5 and $10 \mathrm{~mm}$ and ensiled in three bag silos (approximately $25 \mathrm{t}$ each). Benzoate and $L$. buchneri were applied to the forage at ensiling in aqueous solutions, using an inoculant sprayer adapted to the silo bagger. Application rates were $4.6 \mathrm{~L} / \mathrm{t}$ for the benzoate solution and $1.6 \mathrm{~L} / \mathrm{t}$ for the inoculant. Urea was added to the forage without dilution while it was loaded into the bagging equipment. Silages were stored for approximately nine months.

Rations were formulated (NRC, 2001) considering the average initial live weight $(540 \mathrm{~kg}$ ) and milk production $(18 \mathrm{~kg} / \mathrm{d})$ of the cows and the presence or not of urea in the forage (Table 1). Cows were fed ad libitum (10\% leftovers) once daily when receiving TMRs with silage and twice daily when receiving TMR with fresh sugarcane, considering that fresh chopped sugarcane is easily heated in the bunk. Feed supplied to the cows and feed refused by the group of cows in each treatment were recorded daily and samples of TMRs, silages and fresh sugarcane were taken on three alternate days, during each period of data collection. Samples were dried in air forced dry oven $\left(60^{\circ} \mathrm{C}, 48\right.$ hours $)$, grounded

Table 1 - Composition of experimental total mixed rations

\begin{tabular}{|c|c|c|}
\hline $\begin{array}{l}\text { Ingredient } \\
(\% \text { in ration DM) }\end{array}$ & $\begin{array}{c}\text { Total mixed ration prepared with silage treated } \\
\text { with urea }(5.0 \mathrm{~g} / \mathrm{kg} \text { of fresh forage }-\mathrm{FF})+ \\
\text { sodium benzoate }(0.5 \mathrm{~g} / \mathrm{kg} \mathrm{FF})\end{array}$ & $\begin{array}{l}\text { Total mixed ration prepared with silage } \\
\text { inoculated with } L \text {. buchneri }\left(5 \times 10^{4} \mathrm{cfu} / \mathrm{g} \mathrm{FF} \text { and }\right. \\
\text { total mixed ration prepared with fresh sugarcane }\end{array}$ \\
\hline Fresh sugarcane or silage & 60.0 & 62.5 \\
\hline Ground yellow corn & 16.2 & 14.2 \\
\hline Soybean meal & 11.4 & 10.6 \\
\hline Whole cottonseed & 10.0 & 9.4 \\
\hline Urea & 0.3 & 1.4 \\
\hline Mineral supplement & 2.1 & 1.9 \\
\hline
\end{tabular}


in a Wiley mill through a 1-mm screen and analyzed for acid detergent fiber (ADF), neutral detergent fiber (NDF) and lignin according to Van Soest \& Robertson (1985) and for dry matter, ash, crude protein (CP), ether extract and N-ADF according to AOAC (1990). Content of total digestible nutrients (TDN) in silages and TMRs were calculated according to Weiss et al. (1992).

Milk production was recorded twice daily (6:00 a.m. and 6:00 p.m.) throughout the experimental period. Milk samples were taken at two consecutive milkings, in each period of data collection, forming one composite sample per cow per period. Milk samples were kept refrigerated and sent to be analyzed for fat, crude protein, lactose and total solids in a specialized laboratory (Clínica do Leite, USP, Piracicaba, SP). The following formulas were used to calculate $3.5 \%$ fat corrected milk (FCM) and feed efficiency:

$\operatorname{FCM}(\mathrm{kg})=(0.4324 \times \mathrm{kg}$ of milk $)+(16.216 \times \mathrm{kg}$ of milk fat $)$

Feed efficiency $=\operatorname{kg}$ FCM $\div \operatorname{kg}$ DM consumed

Performance and milk quality parameters were statistically analyzed using the MIXED procedure. In the analysis of feed parameters, differences among treatment means were tested using Student's t-test. Both procedures were carried out using SAS program (SAS, 2003) and significance was declared at $\mathrm{P}<0.05$.

\section{Results and Discussion}

The analysis of experimental forages (Table 2) indicated concentrations of dry matter, neutral detergent fiber and acid detergent fiber within the normal range for the fresh sugarcane (Siqueira et al., 2007; Queiroz et al., 2008). Total digestible nutrients content in the fresh forage was high ( $682 \mathrm{~g} / \mathrm{kg}$ DM), although little information is available in the literature for comparision. Fernandes et al. (2003) reported total digestible nutrients of approximately $630 \mathrm{~g} / \mathrm{kg} \mathrm{DM}$ for sugarcane with different cycles of production. The ensiling process decreased in dry matter content and increase in fiber and protein contents in both silages relative to the fresh forage. These are common aspects observed during ensilage of sugarcane and they result mainly from alcoholic fermentation of sugars by yeasts, which is characterized by high dry matter loss in the form of $\mathrm{CO}_{2}$ and $\mathrm{H}_{2} \mathrm{O}$ (McDonald et al., 1991). The loss of sugars results in the relative increment of PB, NDF and ADF in dry matter (Pedroso et al., 2005) and, in this experiment, it indicates that the additives did not completely inhibit ethanol fermentation in the silages. Content of crude protein in the silage treated with urea + benzoate $(68.6 \mathrm{~g} / \mathrm{kg} \mathrm{DM})$ was within the range normally found in silages treated with the same amount of urea (Schmidt et al., 2007; Pedroso et al. 2008a) and it was probably responsible for TDN in this silage to be similar to TDN in the fresh sugarcane. The lower DM and higher fiber content in the silages reflected in the contents of these components in the respective TMRs but they did not negatively affect TDN in the rations compared to the ration with fresh sugarcane.

The type of silage did not affect dry matter intake(DMI) and milk production among cows fed TMRs produced with the ensiled forage but DMI and milk production were, respectively, $14 \%$ and $6 \%$ lower for these cows compared to cows fed the ration with fresh sugarcane (Table 3). However, fat content was higher in the milk of cows fed silage inoculated with $L$. Buchneri compared to the milk of cows fed fresh sugarcane, causing FCM production to be similar for cows in both treatments. Cows fed the ration with silage treated with urea + benzoate produced milk with intermediate fat content, less FCM than cows fed fresh sugarcane but equal amount of FCM compared to cows fed silage inoculated with $L$. Buchneri. Feed efficiency was higher for cows fed the ration produced with the inoculated silage, intermediate for those that received the silage treated with urea + benzoate and lower for cows fed the ration with fresh sugarcane.

The use of a relatively low proportion of concentrates in the rations (approximately $40 \%$ in DM) allowed for the higher fiber content in the silages to reflect in higher NDF

Table 2 - Chemical composition ${ }^{1}$ of silages, fresh sugarcane and experimental rations

\begin{tabular}{lccccc}
\hline Feed & $\begin{array}{c}\text { Dry matter } \\
(\mathrm{g} / \mathrm{kg} \mathrm{FF})\end{array}$ & $\begin{array}{c}\text { Crude protein } \\
(\mathrm{g} / \mathrm{kg} \mathrm{DM})\end{array}$ & $\begin{array}{c}\text { Neutral detergent } \\
\text { fiber }(\mathrm{g} / \mathrm{kg} \mathrm{DM})\end{array}$ & $\begin{array}{c}\text { Acid detergent } \\
\text { fiber }(\mathrm{g} / \mathrm{kg} \mathrm{DM})\end{array}$ & $\begin{array}{c}\text { Total digestible } \\
\text { nutrients }(\mathrm{g} / \mathrm{kg} \mathrm{DM})\end{array}$ \\
\hline S1 & $311 \pm 4.1 \mathrm{~b}$ & $68.6 \pm 3.2 \mathrm{a}$ & $594 \pm 13.8 \mathrm{a}$ & $382 \pm 11.9 \mathrm{a}$ & $662 \pm 6.5 \mathrm{ab}$ \\
S2 & $298 \pm 5.7 \mathrm{c}$ & $32.2 \pm 1.8 \mathrm{~b}$ & $584 \pm 13.5 \mathrm{a}$ & $393 \pm 8.5 \mathrm{a}$ & $641 \pm 10.3 \mathrm{~b}$ \\
SC & $347 \pm 2.6 \mathrm{a}$ & $19.8 \pm 1.7 \mathrm{c}$ & $481 \pm 19.5 \mathrm{~b}$ & $301 \pm 5.9 \mathrm{~b}$ & $682 \pm 7.1 \mathrm{a}$ \\
TMR1 & $414 \pm 5.1 \mathrm{~B}$ & $142 \pm 3.2 \mathrm{~A}$ & $375 \pm 13.0 \mathrm{AB}$ & $254 \pm 15.2 \mathrm{~A}$ & $739 \pm 11.4 \mathrm{~A}$ \\
TMR2 & $399 \pm 6.4 \mathrm{~B}$ & $143 \pm 5.1 \mathrm{~A}$ & $402 \pm 17.4 \mathrm{~A}$ & $266 \pm 15.9 \mathrm{~A}$ & $720 \pm 9.9 \mathrm{~A}$ \\
TMR3 & $474 \pm 5.1 \mathrm{~A}$ & $139 \pm 10.1 \mathrm{~A}$ & $339 \pm 14.7 \mathrm{~B}$ & $204 \pm 8.2 \mathrm{~B}$ & $747 \pm 12.0 \mathrm{~A}$ \\
\hline
\end{tabular}

${ }^{1}$ Mean \pm standard error

$\mathrm{S} 1$ = Silage treated with urea $(5 \mathrm{~g} / \mathrm{kg}$ fresh forage $-\mathrm{FF})+$ sodium benzoate $(0.5 \mathrm{~g} / \mathrm{kg} \mathrm{FF})$; S2 = silage inoculated with $\mathrm{L}$. buchneri $\left(5 \times 10^{4} \mathrm{cfu} / \mathrm{g}\right.$ FF $)$; SC = fresh sugarcane; TMR1 = total mixed ration prepared with S1; TMR2 = total mixed ration prepared with S2; TMR3 = total mixed ration prepared with SC.

abc - Different lower case letters in the column indicate statistic difference $(\mathrm{P}<0.05)$ in silage parameters; ABC - Different capital letters in the column indicate statistic difference $(\mathrm{P}<0.05)$ in TRM parameters. 
Table 3 - Lactation performance and milk composition of Holstein cows fed total mixed rations produced with fresh sugarcane or sugarcane silages treated with additives

\begin{tabular}{|c|c|c|c|c|}
\hline \multirow[t]{2}{*}{ Item } & \multicolumn{3}{|c|}{ Total mixed ration } & \multirow[t]{2}{*}{$\mathrm{SE}$} \\
\hline & Silage with urea + sodium benzoate & Silage with $L$. buchneri & Fresh sugarcane & \\
\hline Dry matter intake (kg/day) & $18.62 b$ & $18.34 \mathrm{~b}$ & $21.44 \mathrm{a}$ & 0.29 \\
\hline Fat corrected milk (kg/day) & $16.92 b$ & $17.38 \mathrm{ab}$ & $17.89 \mathrm{a}$ & 1.7 \\
\hline Feed efficiency (kg FCM/kg DMI) & $0.91 b$ & $0.95 a$ & $0.83 c$ & 0,01 \\
\hline Fat $(\mathrm{g} / \mathrm{kg})$ & $33.4 \mathrm{ab}$ & $33.8 \mathrm{a}$ & $32.5 b$ & 0.4 \\
\hline Total solids (g/kg) & $120.5 \mathrm{a}$ & $121.0 \mathrm{a}$ & $119.6 a$ & 0.8 \\
\hline
\end{tabular}

Fat corrected milk $=(0.4324 \times \mathrm{kg}$ of milk $)+(16.216 \times \mathrm{kg}$ of milk fat $)$.

abc - Different letters in the same line indicate statistic difference $(\mathrm{P}<0.05)$.

in the respective rations what probably caused lower DMI by cows fed TMRs containing silage compared to those fed the TMR with fresh forage. Allen (2000), in a review of 15 studies, showed a general decline in DMI with increasing NDF concentrations in diets when diets exceeded 25 percent NDF.

It could be argued that high acetic acid content in the silages could also contribute for the observed reduction in DMI, especially by cows fed the silage inoculated with L. buchneri, but there is an indication that acetic acid content in silages per se does not affect DMI (Taylor et al., 2002). Dry matter intake of rations produced with both silages, despite of being inferior to DM intake of the ration produced with fresh forage, was adequate according to NRC (2001), considering live weight, milk production and stage of lactation of the cows.

Lower DMI was probably responsible for the reduction in milk production (approximately 6\%) observed for the cows fed silage in relation to cows fed fresh sugarcane. It is well established that any reduction in DMI will lead to a proportional reduction in milk production if nutrient content in the ration is kept constant (NRC, 2001).

The increment in fat content in the milk of cows fed the silage inoculated with $L$. buchneri probably resulted from a higher acetic acid content in the silage. Acetic acid is one of the main precursors of milk fat and higher amounts of it in the diet may elevate milk fat content and milk production (McCullough et al., 1969). The ability of L. buchneri to cause elevation in acetic acid concentration in traditional silages has been well documented (Driehuis et al., 1999; Ranjit \& Kung; Jr., 2000; Taylor et al., 2002). Although acetic acid concentration was not evaluated in this trial, it should be expected to be higher in the inoculated silage since higher content of the acid was observed in sugarcane silages inoculated with the bacteria in previous works (Mendes et al., 2008; Pedroso et al., 2007).
Data on the performance of dairy cows fed sugarcane silage is scarce. Queiroz et al. (2008) reported small difference but higher DMI by cows fed sugarcane silage inoculated with $L$. buchneri compared to DMI by cows fed the fresh forage (23.5 vs $22.3 \mathrm{~kg} \mathrm{DM} / \mathrm{d}$ ). Milk and $4 \%$ fat corrected milk productions (24.5 and $22.1 \mathrm{~kg} / \mathrm{d}$ on average, respectively) were similar in both treatments. The use of high proportion of concentrates in the diets tested by those researchers (60\% in DM) led to similar content of neutral detergent fiber and acid detergent fiber in the rations, suggesting that other factors, except for fiber content, affected DMI. Those authors could not explain the cause for the higher DMI of the ration containing the silage though.

Mendes et al. (2008) also detected elevation in milk fat and better feed efficiency when lactating goats were fed rations with sugarcane silage (both with and without additive), compared to goats fed the fresh forage. Queiroz et al. (2008) observed the same feed efficiency of $0.95 \mathrm{~kg}$ FCM $/$ kg DMI for cows fed ration produced with silage inoculated with $L$. buchneri. This level of feed efficiency may be considered good since the index obtained by those authors for cows fed ration with corn silage was not much higher(1.13).

Concentrations of crude protein and total solids in milk were not affected by treatment in this experiment, in accordance with Queiroz et al.(2008), but, differently from the findings by those authors, the milk of cows fed silage treated with urea + benzoate had higher lactose content than the milk of cows fed the fresh forage. Mendes et al. (2008) also detected higher lactose in milk of goats fed sugarcane silage compared to goats fed fresh sugarcane. Higher energy content in diets has been reported to result in higher lactose in milk in experiments in which glucose level in blood of cows was markedly elevated (Huber \& Boman, 1966). This does not seem to be the case in this experiment since all rations had the same energy content (TDN). 


\section{Conclusions}

Cows receiving ration produced with sugarcane ensiled with additives may present lower dry matter intake and milk production compared to cows fed ration with the fresh forage although feed efficiency may be improved. Fat content in milk of cows fed silage inoculated with $L$. buchneri may be positively affected, compensating for small reductions in milk production, allowing for the production of $3.5 \%$ fat corrected milk to be similar to production of cows fed fresh sugarcane.

\section{Acknowledgements}

The authors gratefully acknowledge Lallemand Animal Nutrition for supplying the bacterial inoculant.

\section{References}

ALLEN, M.S. Effects of diet on short-term regulation of feed intake by lactating dairy cows. Journal of Dairy Science, v.83, p.1598-1624, 2000.

ALLI, I.; BAKER, B.E.; GARCIA, G. Studies on the fermentation of sugarcane. Animal Feed Science and Technology, v.7, p.411- 417, 1982.

ASSOCIATION OF OFFICIAL ANALYTICAL CHEMISTIS AOAC. Official methods of analysis. 15.ed. Arlington, 1990. v.1, 1117p.

DRIEHUIS, F.; ELFERINK, S.J.W.H.O.; SPOELSTRA, S.F. Anaerobic lactic acid degradation during ensilage of whole crop maize inoculated with Lactobacillus buchneri inhibits yeast growth and improves aerobic stability. Journal of Applied Microbiology, v.87, p.583-594, 1999.

FERNANDES, A.M.; QUEIROZ, A.C.; PEREIRA, J.C. et al. Composição químico-bromatológica de variedades de cana-deaçúcar (Saccharum spp L.) com diferentes ciclos de produção (precoce e intermediário) em três idades de corte. Revista Brasileira de Zootecnia, v.32, p.977-985, 2003.

HUBER, J.T.; BOMAN, R.L. Nutritional factors affecting the solidsnot-fat content of milk. Journal of Dairy Science, v.49, p.816-821, 1966.

McCULLOUGH, M.E.; SISK, L.R.; SMART, W.W.G. Sodium acetate and sodium propionate as additives to all-in-one silage rations for milk protection. Journal of Dairy Science, v.52, p.1605-1608, 1969.

McDonAld, P.; Henderson, A.R.; Heron, S.J.E. The biochemistry of silage. 2.ed. Merlow: Chalcomb Publications, 1991. 340p

MENDES, C.Q.; SUSIN, I.; NUSSIO, L.G. et al. Efeito do Lactobacillus buchneri na fermentação, estabilidade aeróbia e no valor nutritivo de silagem de cana-de-açúcar. Revista Brasileira de Zootecnia, v.37, p.2191-2198, 2008.
NATIONAL RESEARCH COUNCIL - NRC. Nutrient requirement of dairy cattle. 7.ed. Washington: National Academy Press, 2001. 381p.

PEDROSO, A.F.; NUSSIO, L.G.; PAZIANI, S.F. et al. Fermentation and epiphytic microflora dynamics in sugar cane silage. Scientia Agricola, v.62, p.427-432, 2005.

PEDROSO, A.F.; NUSSIO, L.G.; BARIONI JR., W. et al. Performance of Holstein heifers fed sugarcane silages treated with urea, sodium benzoate or Lactobacillus buchneri. Pesquisa Agropecuária Brasileira, v.41, p.649-654, 2006.

PEDROSO, A.F.; RODRIGUES, A.A.; BARIONI JR., W. et al. Características da fermentação e perdas em silagens de canade-açúcar tratadas com aditivos químicos ou inoculantes bacteriano. In: REUNIÃO ANUAL DA SOCIEDADE BRASILEIRA DE ZOOTECNIA, 44., 2007, Jaboticabal. Anais... Jaboticabal: SBZ: UNESP, 2007. (CD-ROM)

PEDROSO, A.F.; NUSSIO, L.G.; LOURES, D.R.S. et al. Fermentation, losses, and aerobic stability of sugarcane silages treated with chemical and bacterial additives. Scientia Agricola, v.65, p.567-691, 2008a.

PEDROSO, A.F.; RODRIGUES, A.A.; SANTOS, F.A.P. et al. Desempenho de tourinhos alimentados com rações preparadas com silagens de cana-de-açúcar tratadas com aditivos químicos ou inoculante bacteriano. In: CONGRESSO NORDESTINO DE PRODUÇÃO ANIMAL, 5.; SIMPÓSIO NORDESTINO DE ALIMENTAÇÃO DE RUMINANTES, 11.; SIMPÓSIO SERGIPANO DE PRODUÇÃO ANIMAL, 2008, Aracaju. Anais... Aracaju: SNPA, 2008b. (CD-ROM)

QUEIROZ, O.C.M.; NUSSIO, L.G.; SCHMIDT, P. et al. Silagem de cana-de-açúcar comparada a fontes tradicionais de volumosos suplementares no desempenho de vacas da alta produção. Revista Brasileira de Zootecnia, v.37, p.358-365, 2008.

RANJIT, N.K.; KUNG JR., L. The effect of Lactobacillus buchneri, Lactobacillus plantarum, or a chemical preservative on the fermentation and aerobic stability of corn silage. Journal of Dairy Science, v.83, p.526-535, 2000.

SCHMIDT, P.; MARI, L.J.; NUSSIO, L.G. et al. Aditivos químicos e biológicos na ensilagem de cana-de-açúcar. 1. Composição química das silagens, ingestão, digestibilidade e comportamento ingestivo. Revista Brasileira de Zootecnia, v.36, n.5, p.1666-1675, 2007.

SIQUEIRA, G.R.; REIS, R.A.; SCHOCKEN-ITURRINO, R.P. et al. Perdas de silagens de cana-de-açúcar tratadas com aditivos químicos e bacterianos. Revista Brasileira de Zootecnia, v.36, n.6, p.2000-2009, 2007.

STATISTICAL ANALYSIS SYSTEM - SAS. System for Microsoft Windows. Release 9.1, Cary, 2003 (CD-ROM).

TAYLOR, C.C.; RANJIT, N.J.; MILLS, J.A. et al. The effect of treating whole-plant barley with Lactobacillus buchneri 40788 on silage fermentation, aerobic stability, and nutritive value for dairy cows. Journal of Dairy Science, v.85, p.1793-1800, 2002.

VAN SOEST, P.J.; ROBERTSON, J.B. Analysis of forages and fibrous foods. Ithaca: Cornell University, 1985. 202p.

WEISS, W.P.; CONRAD, H.R.; ST. PIERRE, N.R. A theoreticallybased model for predicting total digestible nutrient values of forages and concentrates. Animal Feed Science and Technology, v.39, p.95-110, 1992. 